\title{
FESTIVAL FOLCLÓRICO DE PARINTINS: IDENTIDADES E MULTITERRITORIALIDADES A PARTIR DAS TOADAS DOS BOIS CAPRICHOSO E GARANTIDO
}

\author{
Fernando Rossetto Gallego Campos \\ Instituto Federal de Santa Catarina (IFSC) - Câmpus Chapecó \\ Professor do Programa de Pós-Graduação da Universidade Federal da Fronteira Sul (UFFS) \\ fernando.campos @ifsc.edu.br
}

\begin{abstract}
RESUMO
O Festival Folclórico de Parintins, marcado pelo confronto simbólico dos bois-bumbás Garantido e Caprichoso, é uma manifestação cultural de grande presença na vida cotidiana parintinense, através de seu espaço de representação. Entretanto, o alcance do evento vai além da escala local, tendo as toadas como uma de suas principais manifestações. $O$ objetivo deste trabalho é analisar como as toadas produzem e reproduzem discursos de cunho indentitário e de que forma eles criam e reforçam a construção de multiterritorialidades. As toadas de 2019 foram analisadas a partir da Análise do Discurso e da espacialidade lefebvriana. Conforme a escala de referência discursiva e temáticas, elas foram divididas nas escalas: local; estadual/amazônica; nacional e global. Na escala local, há discursos de identificação com os bois e com Parintins. Na escala estadual/amazônica, discursos tendem a construir uma identidade amazônica partindo de universos simbólicos caboclo e indígena. Na escala nacional, os bois reforçam sua ancestralidade mestiça e se autoafirmam brasileiros e atores da cultura popular do país. Na escala global, preservação da Amazônia, religiosidade e pautas sociais fazem parte da formação discursiva. Os discursos produzidos nas toadas têm como característica articular diferentes escalas e identidades, construindo multiterritorialidades para além do tempo e espaço do Festival.
\end{abstract}

Palavras-chave: Boi-bumbá. Discurso. Espacialidade. Espaços de representação. Escala.

\section{FESTIVAL FOLCLÓRICO DE PARINTINS: IDENTITIES AND MULTITERRITORIALITIES FROM CAPRICHOSO AND GARANTIDO BOIS-BUMBÁS}

\begin{abstract}
Marked by the symbolic confrontation of Caprichoso and Garantido bois-bumbás (a characterized ox), Festival Folclórico de Parintins is a cultural manifestation with a large presence in Parintins' everyday life. However, the event reaches beyond the local scale, having the toadas (typical songs) as one of its main manifestations. The work aims at analyzing how the toadas produce and reproduce identitary discourses and how they create and reinforce multiterritorialities. 2019's toadas were analyzed through Discourse Analysis and Lefebvrian spaciality. According to the discourse reference scale and themes, the toadas were divided in local, state/Amazonic, national and global scales. In the local scale there are discourses of identification with the oxen and with Parintins. In the state/Amazonic scale, there is a discourse pattern in order to build an Amazonic identity from indigenous and caboclo symbolic universes. In national scale, there is an effort by the oxen to affirm themselves as Brazilians and as national popular cultural actors, and also to reinforce their miscegenated and northeastern ancestry. In global scale, Amazonic preservation, religiosity and relevant social topics are part of the discursive formation. The discourses on toadas articulate different scales and identities, building multiterritorialities beyond Festival's time and space.
\end{abstract}

Keywords: Boi-bumbá. Discourse. Spaciality. Representational spaces. Scale.

\section{INTRODUÇÃO}

Reconhecido como patrimônio cultural do Brasil pelo IPHAN em 2018, o Festival Folclórico de Parintins $^{1}$ - caracterizado pela disputa simbólica entre os bois Caprichoso (azul) e Garantido

\footnotetext{
1 O município de Parintins se localiza no leste do Amazonas (limítrofe ao estado do Pará) e possui 115.363 habitantes (IBGE, 2020) em uma área de $5.952,333 \mathrm{~km}^{2}$. É o município mais populoso da Região Intermediária

$\begin{array}{lllll}\text { Caminhos de Geografia } & \text { Uberlândia } & \text { v. 22, n. } 84 & \text { Dez/2021 } & \text { p. 169-186 Página } 169\end{array}$
}


(vermelho) - é a mais importante festa folclórica da Amazônia, sendo elemento fundamental da espacialidade e da socialidade amazônida. Possui uma enorme capacidade de produzir e reproduzir discursos sobre o espaço e do espaço (SHIELDS, 1999), bem como representações sociais (MOSCOVICI, 2003). O que é particularmente interessante é que estas representações e discursos circulam para além da temporalidade do festival em si (junho), ou seja, fazem parte da vida cotidiana parintinense e, em certa medida, amazônica durante todo o ano. Além das cores e símbolos, a forma mais eficiente de produzir e reproduzir representações e discursos são as toadas, canções típicas do Festival, que tanto narram lendas e rituais indígenas quanto exaltam os bois, Parintins e a Amazônia. Segundo Cardoso (2013, p. 6), elas "expressam a linguagem, a música e a cultura de Parintins. E é a forma encontrada pelos compositores locais de cantarem as belezas, a história e a cultura do povo parintinense".

Todo ano, ambos os bois lançam mais de vinte toadas, cada uma delas para um momento específico da apresentação nos três dias na arena, sendo fundamentais nas narrativas dos bois, pois suas letras são traduzidas em imagens (alegorias, fantasias, encenações) (SILVA, 2009). Em geral, as toadas são lançadas em abril e tocam em festas, bares e rádio até o Festival, mas também depois em outros festejos, como o Carnaboi, em Manaus. Além disso, estão disponíveis no site dos bois, em mídia física e em serviços de streaming. Trata-se do gênero mais apreciado em Parintins, mas também um dos mais populares na Amazônia toda.

A partir do lançamento das toadas em CD, na década de 1990, este gênero musical se popularizou no Brasil todo. A toada Vermelho, do Garantido, regravada por Fafá de Belém, se tornou um dos grandes sucessos de 1996, tocando amplamente nas rádios e em programas de televisão. No mesmo ano, o grupo Carrapicho regravou diversas toadas e conseguiu vendas expressivas no mundo todo, sobretudo com Tic Tic Tac, também do Garantido, que alcançou o topo das paradas na França e Portugal. Um ano depois, a toada Ritmo Quente, gravada pelo Caprichoso e pelo grupo Canto da Mata, se tornou bastante popular, apesar de sua difusão ter sido geograficamente mais restrita. Desde então, as toadas têm sido usadas como formas de exaltar o boi, o Festival e elementos culturais amazônidas, mas também como formas de expressar e reforçar discursos identitários, com características multiescalares - que vão do local até o global, passando pelo regional e o nacional - e que ajudam a produzir multiterritorialidades (HAESBAERT, 2004). A década de 1990, também foi de grandes inovações rítmicas e temáticas, pela adição de instrumentos, ritmos e temas indígenas.

As toadas continuam se modificando com o tempo, adicionando elementos musicais, mas também discursivos, reveladores de relações espaciais. Desta forma, o objetivo deste artigo é analisar como as toadas produzem e reproduzem discursos de cunho indentitário e de que forma eles criam e reforçam a construção de multiterritorialidades. Devido ao grande volume de toadas produzidas pelos bois, optamos por analisar apenas as 51 toadas lançadas oficialmente em 2019 (28 pelo Caprichoso e 23 pelo Garantido). As toadas serão analisadas a partir dos instrumentos da Análise do Discurso (MAINGUENEAU, 1997; PECHEUX, 2006). Além da análise do discurso, este estudo também teve como procedimento metodológico a pesquisa bibliográfica - tanto de autores que embasam a discussão teórica quanto autores que contribuem para a discussão temática acerca do Festival de Parintins - o qual se articulou com a análise do discurso.

\section{PARINTINS, ESPACIALIDADE E DISCURSO}

Diversos artigos pautaram a discussão das toadas e do Festival de Parintins em diversas dimensões. Fiori e Rodrigues (2014) classificam o Festival como um megaevento regional, pois mobiliza recursos financeiros e paixões, sendo capaz de articular diversas escalas da vida social. Silva (2010) demonstra as rupturas na forma de produção artística dos bumbás, em decorrência da espetacularização, principalmente a partir do fim da década de 1980. Brito, Ribeiro e Souza (2010) analisaram se o Festival de Parintins estava alinhado com a perspectiva do desenvolvimento local sustentável, concluindo que há uma distância desta perspectiva e que a cultura local - por mais que propale um discurso ecológico - é bastante influenciada pela ideologia do capital. Já Gatto Cardoso e Soares (2017) demonstram que o Festival não se limite a produto da indústria cultural, porque as relações simbólicas produzidas independem da lógica de mercado e representam os sujeitos parintinenses. Este universo simbólico do Festival é analisado também por Silva (2011), que conclui

de Parintins e segundo do estado (atrás de Manaus). Parintins se localiza no arquipélago de Tupinambarana chamado comumente de Ilha de Tupinambarana, pois acreditava-se ser uma ilha única (no entanto, são quatro ilhas separadas por paranás).

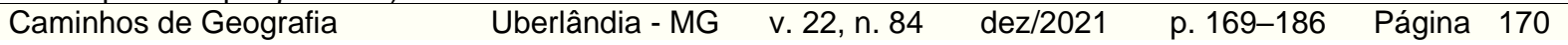


que este evento cultural celebra as relações entre homem e natureza, mas também um espaço de denúncia, bem como de "falar sobre os dramas de vida e de morte do povo amazônico através da música" (p. 244). Por outro lado, Cardoso (2013) adverte sobre o perigo da mercantilização do Festival desenraizar a cultura parintinense e acabar com o tradicional.

No entanto, o que pretendemos é destacar a dimensão espacial do Festival e as toadas como tanto discurso sobre espaço quanto discurso do espaço. Gonzaga (2002) trata de uma "geografia mítica do boi”, mas não avança significativamente na discussão espacial. Já Furnaletto (2011, p. 1), para quem o boi-bumbá é a "expressão máxima da autenticidade cultural da região Norte do Brasil", relaciona as representações do festejo com identidade territorial, além de enfatizar as toadas como elemento central neste universo simbólico. Já Cavalcanti (2000, p. 1040) atribui ao Festival a condição de "moderno movimento nativista que elegeu imagens indígenas como metáforas para a afirmação de uma identidade regional cabocla". Ao analisar elementos relacionados às performances dos boisbumbás, Silva (2009) destaca a identidade amazônica como uma das diversas possibilidades de construção discursiva no Festival.

Ao fazer uma leitura de obra de Lefebvre, Shields (1999) destaca relações entre espaço e discurso. Segundo o autor, os discursos sobre o espaço (discourses on space) estão ligados a dimensão do concebido, das representações do espaço (LEFEBVRE, 1991). Esta instância é a do planejamento urbano e se contrapõe às práticas espaciais (dimensão do percebido), que é fundamentalmente alienada (devido sua relação com as representações do espaço). Desta maneira, os discursos sobre o espaço têm forte dimensão material, mas também podem ser simbólicos, expressando relações de poder. Por outro lado, há os discursos do espaço (discourses of space) - que são eminentemente simbólicos, apesar de poderem também se materializar. Estes operam em um meta-nível, admitindo uma pluralidade de discursos no processo de produção do espaço (SHIELDS, 1999). Por operarem fundamentalmente na dimensão do vivido, estão relacionados aos (múltiplos) espaços de representação, instância da espacialidade em que os sujeitos têm experiências plenamente vividas (momentos de presença) (LEFEBVRE, 1991).

A dialética da triplicidade da espacialidade é, segundo Lefebvre (1991), composta pelas instâncias: práticas espaciais (percebido), representações do espaço (concebido) e espaços de representação (vivido). A vida cotidiana das práticas espaciais funciona como afirmação (tese), as representações do espaço como negação (antítese) e os espaços de representação como negação da negação (diversidade) e não como síntese, que é a própria espacialidade (LEFEBVRE, 1991; SHIELDS, 1999). Assim, os espaços de representação são a instância do plenamente vivido, uma vez que trazem à vida cotidiana momentos de presença, rompendo com a alienação (LEFEBVRE, 2006).

Os espaços de representação se constituem por universos simbólicos próprios, mas também em constante interação com as instâncias da espacialidade. Dentro deste universo, podemos encontrar os discursos sobre o espaço, mas principalmente do espaço. No redimensionamento do espaço de representação (GIL FILHO, 2003; AUTOR, 2018), o discurso é uma das categorias de mediação (junto com símbolos, mitos e estruturações identitárias), ou seja, realiza a ponte entre as categorias centrais (fatos, práticas sociais e relações) e os reinos (organização, ethos e organização), que se manifestam como representações sociais. Desta maneira, podemos averiguar que os discursos são formas de ligação do universo reificado - neste caso dos bois-bumbás como associações folclóricas e do universo consensual, típico das representações sociais que circulam a partir da apropriação dos discursos e de outras categorias de mediação (MOSCOVICI, 2003). Neste sentido, discursos e estruturações identitárias são elementos que dialogam constantemente, sendo um produtor do outro. Da mesma forma, as estruturações identitárias - cada vez mais fluídas e híbridas (HALL, 2005; MAFFESOLI, 2006) - são expressões de formações discursivas, assim como os diversos discursos produzidos são expressões das múltiplas estruturações identitárias.

Os novos processos de estruturação identitária perdem o caráter fixo e estabilizante, passando a múltiplas, fluidas, híbridas e multiescalares identidades, ligados à pós-modernidade (HAESBAERT, 2004; HALL, 2005; MAFFESOLI, 2006). Na pós-modernidade (muito mais como novos arranjos do que como período histórico), o espaço social se organiza como espaço diferencial (LEFEBVRE, 1991). Nesta nova organização, percebe-se a prevalência dos espaços de representação sobre as demais instâncias da espacialidade - que continuam se manifestando, mas geralmente em diálogo com os elementos simbólicos e culturais da dimensão do vivido. O espaço diferencial é justamente a organização que permite estas identidades múltiplas, bem como a diversidade de discursos por seus habitantes (SHIELDS, 1999), além das manifestações hedonistas e orgiásticas (MAFFESOLI, 2004). 
Este parece ser o caso de Parintins, uma vez que o Festival Folclórico e seu universo simbólico (ou, poderíamos dizer, seu espaço de representação) está presente tanto no cotidiano das pessoas durante $o$ ano todo (práticas espaciais) quanto acaba pautando e influenciando as ações técnicas do planejamento urbano (representações do espaço). Nesta configuração, do espaço diferencial de Parintins, os discursos relevantes não são apenas aqueles sobre o espaço, mas também aqueles do espaço, como os das toadas. Tais discursos também versam e se apropriam de elementos de múltiplas escalas (desde a local até a global), sendo capaz de articulá-las, produzindo multiterritorialidades e um grande número de complexas representações sociais.

No caso específico das toadas, sua composição é feita por um grupo bastante restrito (enunciadores) e é necessário pensar que elas são destinadas não apenas para os brincantes/torcedores de Parintins, mas também para aqueles de toda Amazônia e, mesmo que não tenham uma ligação afetual tão forte com os Bois, pessoas de todo o Brasil (e, eventualmente, do mundo) (enunciatários) (PÊCHEUX, 2006).

\section{RESULTADOS E DISCUSSÕES}

Para tornar a discussão mais objetiva e a apresentação dos resultados mais didática, optamos por analisar as toadas por temáticas que dividimos em quatro escalas: (1) local; (2) estadual e amazônica; (3) nacional; e (4) global. Trata-se de uma divisão apenas esquemática, pois, como já discutimos, há uma intensa articulação escalar no discurso das toadas dos bois-bumbás. As toadas do Caprichoso serão transcritas em azul e as do Garantido, em vermelho.

\section{Escala local}

O primeiro aspecto que apresentaremos da escala local é a identificação dos brincantes com os boisbumbás e seus símbolos, a qual produz uma oposição binária (FIORI; RODRIGUES, 2014). Tal aspecto está presente em praticamente todas as toadas, mas citaremos alguns dos exemplos mais explícitos desta construção identitária tão fundamental na vida cotidiana de Parintins, pois não é possível ficar indiferente aos bois (mesmo em períodos fora do Festival). No entanto, o Festival é momento de declaração de amor do brincante ao seu boi. As toadas trazem efeitos de sentido de amor eterno e incondicional ao boi, como é possível observar nos seguintes trechos:

Me faz enlouquecer/Vem essa arena acender/Meu boi de pano domador/Jamais te deixarei/Por ti enfrento o que vier/Por que eu te amo! Meu boi! ${ }^{2}$;

Eu sou/Caprichoso até morrer/É esse boi que encanta essa galera/É esse boi que encanta essa nação/É tão bom/Sentir a adrenalina no meu peito/O amor que transborda essa galera/A magia que envolve o torcedor/é pura emoção/[...]/Declaro o meu amor por você/Me faz sorrir, me faz vibrar/Pra sempre eu vou te amar/Jamais te abandonarei/Jamais eu te deixarei/Minha loucura, meu boizão/Minha maior inspiração/Mistura de sentimentos/A vida me fez Caprichoso/Fiz do Caprichoso o meu amor/Eu sou/Sou azul até morrer ${ }^{3}$;

Meu boi, meu boi/A paixão que me envolve por inteiro/Que me dá forças, me conforta/E faz continuar/[...]/Tradição que percorre em minhas veias/Para o mundo inteiro eu declaro este amor/Caprichoso, Caprichoso/Touro negro meu amor ${ }^{4}$;

Vem meu Garantido/Meu eterno amor/Minha paixão/A festa já vai começar/Meu canto é pura poesia/Para declarar o amor vermelho e branco/Viajo nessa fantasia/Ao encontro da mais linda emoção/Meu amor primeiro/Minha inspiração/A oitava maravilha/Pura perfeição/O vermelho é a chama que incendeia/O meu coração/[...]/O melhor boi do mundo/É o meu boi Garantido/Traz o coração na testa/E o calor dessa paixão ${ }^{5}$;

\footnotetext{
2MORAES, C.; LIMA, E.; SILVA, D. Rebojo. In: CAPRICHOSO, Um canto de esperança para Mátria Brasilis. Disponível em: https://boicaprichoso.com/player.asp?t=594.

${ }^{3}$ MIRANDA, R.; NOVAES, R.; ROSENHA. A vida me fez Caprichoso. In: CAPRICHOSO, Um canto de esperança para Mátria Brasilis. Disponível em: https://boicaprichoso.com/player.asp?t=598.

${ }^{4}$ MAIA, E.; MAIA FILHO, E. Caprichoso: um canto novo de esperança. In: CAPRICHOSO, Um canto de esperança para Mátria Brasilis. Disponível em: https://boicaprichoso.com/player.asp?t=605.

${ }^{5}$ FILHO, M.; BARBUGIAN, D.; COELHO, J. O melhor boi do mundo. In: GARANTIDO. Nós, o povo!. Disponível em: https://www.youtube.com/watch?v=LvxQ0rigR80.

\begin{tabular}{llllll}
\hline Caminhos de Geografia & Uberlândia - MG & v. 22, n. 84 & dez/2021 & p. 169-186 Página 172
\end{tabular}
}


Em uma só voz, em um só coro/Em uma só paixão, em uma só nação/Dispara o coração/Acelerado, bombeando sentimento no corpo do torcedor/Esse é o nosso sentimento/Vem de dentro e vai crescendo/Rasga o peito e bota pra fora esse amor/Avassalador/[...]/Garantido eu sou ${ }^{6}$.

A garantia que esse amor é infinito/E só acaba quando no universo/Não houver mais o sol/Meu amor é vermelho/Sem freio, descomunal/Meu amor é por inteiro/E o tempo dele é imortal?.

Nestes trechos, em geral, o enunciatário é um eu que assume o lugar daquele que canta a música (ou seja, não é o eu do compositor ou do levantador de toadas/cantor) ou um nós, recurso discursivo que fomenta a identificação não apenas com o boi, mas com outros torcedores daquele mesmo boi (MAINGEUNEAU, 1997). O efeito de sentido de pertencimento é potencializado também com o uso do termo meu boi e suas variações, demonstrando uma ligação especial entre o boi e aquele brincante específico que canta a toada. Este discurso, por mais que não seja explicitamente espacial, possui uma dimensão territorializante muito forte, pois a declaração de amor por um dos bois-bumbás é a negação do outro (base da construção de identidades modernas), mas também, considerando a escala local, é uma afirmação de pertencimento a uma parte da cidade de Parintins e parte de uma "nação" ou de um "povo" (termos usados nas toadas), mas com diálogo com outras escalas, já que ser torcedor de um dos bois durante o Festival não implica necessariamente participar da vida cotidiana de Parintins.

A evocação desta identidade com um dos bois-bumbás também se dá por determinados elementos simbólicos que distinguem Caprichoso e Garantido, sobretudo as suas cores, como é possível perceber em alguns dos trechos destacadas anteriormente. Neste sentido, "vestir azul" ou "vestir vermelho" equivale a uma declaração de amor aos bois, pois quem é Caprichoso não veste vermelho e quem é Garantido não veste azul (CAVALCANTI, 2000): "Nessa festa eu vou, eu vou brincar de boi/[...]/Vou vestir azul e branco8"; "O meu povo é assim/Veste a camisa encarnada".

A divisão em cores é simbólica, mas se materializa no espaço de forma visível entre os torcedores (nas arquibancadas do bumbódromo, em que é proibido entrar com a cor do bumbá contrário ou mesmo nas ruas de Parintins), mas também na cidade de Parintins. A mesma divisão do Bumbódromo (leste azul e oeste vermelho) se reproduz na cidade (a leste, os bairros da "Cidade Caprichoso", como Francesa e Palmares; e a oeste, a "Cidade Garantido", abrange a Baixa do São José). Apesar desta divisão da cidade ser informal, encontra nas representações do espaço reforço de discursos sobre o espaço. As ruas que margeiam o Bumbódromo levam o nome das baterias de cada um dos bois: a leste está a Rua Marujada (Caprichoso) e a oeste a Rua Batucada (Garantido). As placas da "Cidade Caprichoso" são azuis e as da "Cidade Garantido" são vermelhas Na faixa central, limítrofe entre as duas "Cidades", há uma zona neutra, que abrange o Bumbódromo, a Catedral de Nossa Senhora do Carmo e o cemitério (CAVALCANTI, 2000; FIORI; RODRIGUES, 2014). Nesta parte da cidade, as placas misturam azul e vermelho. Nas casas também se pode perceber uma territorialização da paixão pela pintura de muros, grades e da própria casa nas cores dos bois. No lado oeste, a maioria das casas pintadas são vermelhas, mas é possível encontrar casas azuis (do contrário). O mesmo ocorre no lado Caprichoso. Isto demonstra que os processos identitários podem ocorrer a partir dos discursos sobre o espaço, mas também apesar deles, como discursos do espaço.

Além dos discursos sobre o espaço do poder público, que se apropria das cores dos bois-bumbás, há os próprios discursos do espaço, produzidos pelos bois. Neste sentido, as toadas, são expressões da ligação dos parintinenses com a cidade, com a llha de Tupinambarana ${ }^{10}$ e mais especificamente com os bairros dos bois-bumbás.

${ }^{6}$ AGUIAR, A.; VALÉRIO, M.; AGUIAR, V.; MARQUES, N. Legião vermelha. In: GARANTIDO. Nós, o povo!. Disponível em: https://www.youtube.com/watch?v=iQerraf7tll.

${ }_{7}^{7}$ AGUIAR, A. Garantido imortal. In: GARANTIDO. Nós, o povo!. Disponível em: https://www.youtube.com/watch?v=f9 2IOQjD6I.

${ }^{8}$ BASTOS, G.; KAWAKAMI, G. Um canto de esperança para Mátria Brasilis. In: CAPRICHOSO, Um canto de esperança para Mátria Brasilis. Disponível em: https://boicaprichoso.com/player.asp?t=593.

${ }^{9}$ ANSELMO, J.; BULCÃO, B.; GADELHA, R.; ANSELMO, N. Meu nome é povão. In: GARANTIDO. Nós, o povo!. Disponível em: https://www.youtube.com/watch?v=ZUhKc02ihr8.

${ }^{10}$ A llha de Tupinambarana - tecnicamente um arquipélago, conforme já mencionado - se localiza no leste do Amazonas e possui $11.850 \mathrm{~km}^{2}$. Ela abriga territórios de seis municípios amazonenses: Parintins, Itacoatiara, Nova Olinda do Norte, Barreirinha, Urucurituba e Nova Vista do Ramos.

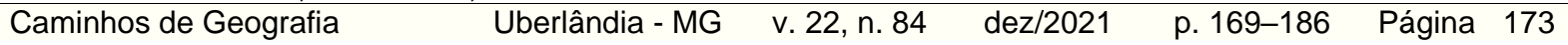


No caso da llha de Tupinambarana, o efeito de sentido produzido pelo discurso de ambos os bois é de um caráter mítico da ilha, de um lugar especial tanto sob o ponto de vista afetual, na constituição de um altar (MAFFESOLI, 2004) (referindo-se como "minha ilha"), quanto sob o ponto de vista fantástico, na constituição de um território-lugar que rompe com as práticas espaciais cotidianas, irrefletidas e alienadas (ideia de "ilha encantada"). O primeiro caso pode ser observado em várias toadas, como no seguinte trecho: "Faz festa e folia, vem boi vem/Brinca na minha ilha, vem boi vem/Traz o azul das contas do meu colar11". Já o segundo caso, está presente em duas toadas específicas de 2020: "Nas aldeias da ilha encantada/Todos os índios se enfeitam pra brincar"12" e "Boa noite/Pra quem veio de tão longe!/[...]/Pra ver/Pra crer/Sentir/Que a festa é real/Que a ilha existe ${ }^{13 "}$. Esta última reforça do caráter fantástico, mas também adiciona interpretação de representações sociais de turistas de incredulidade de que uma festa tão grandiosa é celebrada em uma ilha no interior do Amazonas.

No caso da cidade de Parintins, é bastante comum as toadas utilizarem Parintins como referência espacial e sinônimo de lugar. Apesar de que o termo lugar não esteja sendo utilizado com rigor científico da Geografia, é comum encontrar toadas em que lugar se torna sinônimo de porção do espaço com o qual os sujeitos mantêm relações afetivas, que possui um significado simbólico. É o caso dos seguintes trechos, em que lugar se refere a Parintins, mas não apenas como uma divisão territorial, mas sim como um espaço especial para os dois bumbás: "Vem linda vaqueirada/No bailado ritmado do meu boi-bumbá/Vem! Cortejando a estrela da festa/Touro negro é o rei desse lugar/Vaqueiros do meu boi-bumbá14"; e "Brilha em Parintins uma festa com a cara da gente/Um boi de promessa, o mais campeão do lugar ${ }^{15 " .}$

No entanto, esta ligação afetual com o espaço se manifesta de maneira especial quando os boisbumbás se referem aos seus bairros ou regiões da cidade. No caso do Caprichoso, estes locais são a Francesa e o Palmares, como pode ser observados nos trechos: "Na festa do boi do Palmares/O povo é feliz"16" e "Firmo o pé na Francesa/E não arredo da brincadeira/Sou folclore, sou caboclo/Pra mátria Brasil apresento/O meu boi Caprichoso ${ }^{17 " . ~ N o ~ c a s o ~ d o ~ G a r a n t i d o, ~ a ~ r e f e r e ̂ n c i a ~ e ́ ~ a ~ B a i x a ~ d o ~}$ São José, mas também o termo perreché (um neologismo para pé rachado, que alude ao caráter popular - parte forte do discurso do Garantido - do seu torcedor): "Quem comanda é a galera/Quando desce lá da Baixa/Os camisas encarnada/A trincheira está armada/Uma legião vermelha/Multidão que segue o Boi18" e "Arria logo outra grade/Que a galera aqui na Baixa quer brincar de boi/Ser perreché, pra quem quiser, pode chegar, pra quem vier ${ }^{19 "}$.

O uso dos bairros, referências geográficas ou símbolos do contrário também aparece em uma formação discursiva típica do Festival de Parintins, que é a provocação de um boi em relação ao outro. Esta tradição vem desde a época em que os bois-bumbás eram brincados nas ruas e em que não raramente as provocações extrapolavam as toadas e versos de declamados e os brincantes partiam para confrontos físicos (SILVA, 2009). Atualmente, a formação discursiva de provocação, própria dos torcedores não apenas durante o Festival mas na vida cotidiana de Parintins, durante as apresentações dos bois, é característica do amo do boi, que faz rimas exaltando seu próprio boi, mas também provocando o contrário. No entanto, este discurso está presente em algumas toadas dos bois, como a seguinte: "Ele vai balançar/Vai estremecer/E o contrário pra Baixa vai correr/E o

\footnotetext{
${ }^{11}$ NAKANOMI, E.; BARBOSA, R.; BARBOSA JR., R. Boi de encantaria. In: CAPRICHOSO, Um canto de esperança para Mátria Brasilis. Disponível em: https://boicaprichoso.com/player.asp?t=604.

${ }^{12 K A W A K A M I, ~ G . ; ~ B A S T O S, ~ G . ~ T r i b o ~ C a p r i c h o s o . ~ I n: ~ C A P R I C H O S O, ~ U m ~ c a n t o ~ d e ~ e s p e r a n c ̧ a ~ p a r a ~ M a ́ t r i a ~}$ Brasilis. Disponível em: https://boicaprichoso.com/player.asp?t=595.

${ }^{13}$ DIAS, E.; MOURA, M.; KENNEDY, J.; AGUIAR, A. Boi brinquedo de amor. In: GARANTIDO. Nós, o povo! Disponível em: https://www.youtube.com/watch?v=roPblg2xKFc .

${ }^{14}$ FERREIRA, A. MAGNO, L. C.; BULCÃO, M. L. Galope da emoção. In: CAPRICHOSO, Um canto de esperança para Mátria Brasilis. Disponível em: https://boicaprichoso.com/player.asp? $t=600$.

${ }^{15}$ DIAS, E.; MOURA, M.; KENNEDY, J. Viva São João. In: GARANTIDO. Nós, o povo!. Disponível em: https://www.youtube.com/watch?v=pr8zExz2X-M.

${ }^{16}$ DÚ SAGRADO, P.; MEDEIROS, A. Rainha do povo azulado. In: CAPRICHOSO, Um canto de esperança para Mátria Brasilis. Disponível em: https://boicaprichoso.com/player.asp?t=596.

${ }_{17}$ BELO; CIDADE, A. O mais belo de Parintins. In: CAPRICHOSO, Um canto de esperança para Mátria Brasilis. Disponível em: https://boicaprichoso.com/player.asp?t=601.

${ }^{18}$ AGUIAR, A.; VALÉRIO, M.; AGUIAR, V.; MARQUES, N. Legião vermelha. In: GARANTIDO. Nós, o povo!. Disponível em: https://www.youtube.com/watch?v=iQerraf7tll.

${ }^{19}$ AGUIAR, A. Povo do garrote. In: GARANTIDO. Nós, o povo!. Disponível em: https://www.youtube.com/watch?v=gtWBh900svk. 
contrário lá pra Baixa vai se esconder!20". Neste trecho, o Caprichoso provoca o Garantido (uma característica discursiva é que nunca um boi menciona o nome do outro, usando geralmente o termo "contrário") brincando com o orgulho que este tem de sua região da cidade, transfigurando-o em um esconderijo.

Além dos bairros, outros elementos simbólicos do boi contrário são utilizados para provocação. Um deles são símbolos exaltados por cada um dos bois, como suas cores (Garantido vermelho e Caprichoso azul) e seus símbolos (Garantido coração e Caprichoso estrela). O Caprichoso lançou mão deste recurso discursivo em suas toadas oficiais: "Caprichoso!/A estrela conquistou o coração/Do caboclo e do povo de além-mar/Sua história em brincadeira conta em versos/O folclore popular21" e "Vai atingir teu coração de azul/Vou te mostrar o que é vencer na arena22". No primeiro trecho, a expressão "a estrela conquistou o coração" faz um jogo de duplo sentido, que pode ser interpretado como se o Boi Caprichoso (estrela) conquistou o coração de seu torcedor, mas também que o Boi Caprichoso dominou e venceu seu rival Garantido (cujo símbolo é o coração). No segundo trecho, é possível perceber que o enunciatário já não é mais o torcedor do Caprichoso nem os jurados ou visitantes, mas sim os torcedores do Garantido, pois usa-se a segunda pessoa do singular. Quem terá o coração atingido de azul, em uma situação que o próprio Caprichoso crê como improvável, é o torcedor do Garantido, tanto que é esse mesmo torcedor que o Caprichoso pretende derrotar no Bumbódromo (constantemente referido como "arena"). Cardoso (2013) aponta o jogo de palavras, a pesquisa e a utilização da linguagem como características das toadas. Já o Garantido brincou o tema do Capricho, que era Mátria: "Sem o povo, não existe pátria/Não existe mátria/Sem história e sem cultura/O mundo é terra sem nada"(Festa da liberdade) ${ }^{23}$. A brincadeira alude também ao tema do próprio Garantido (Nós, o povo!), tentando mostrar superioridade inclusive na escolha do tema de 2020.

Através da formação discursiva dos bois-bumbás, o Festival se transforma metaforicamente em uma guerra, o Bumbódromo em um campo de combate e os torcedores em guerreiros - que vestem seus uniformes da cor dos bois, que se transmutam em tribos indígenas ou se tornam protetores de uma "nação": "Somos o povo Garantido/Preparado eu tô/Pra guerra agora eu vou/Armado até os dentes/De cara pintada na arquibancada/Vou me entregar/E ser um só com a nação do Boi Garantido/É o clã vermelho esse povo24" e "Com a cara pintada de azul/Preparados pra guerra na arena/No sangue a garra de ser campeão/É de raça a galera tribal/Toda tribo bate o pé no chão/Todos preparados pra guerra das cores ${ }^{25}$ ". É possível observar que o discurso de guerra se apoia em elementos simbólicos, de duas nações defendendo seus territórios (neste caso específico, suas territorialidades), e não de um discurso de violência ou confronto corporal - como é comum de se encontrar em músicas de torcidas organizadas de futebol. Trata-se de uma "disputa por legitimidade", de ser "o genuíno representante da cultura popular" (SILVA, 2011, p. 236).

Também diferente do futebol, em que a torcida pode, no máximo, influenciar no desempenho das equipes em campo, no Festival de Parintins, as torcidas (chamadas de galeras são um item que pontua, tendo o mesmo peso que cada um dos demais itens). Portanto, é necessário que haja animação inerente à paixão de cada torcedor na arquibancada do bumbódromo, mas também que haja um certo nível de organização e coordenação dos movimentos/coreografias das galeras. Desta forma, as torcidas organizadas de ambos os bois têm grande importância e, apesar de a galera ser a referência do discurso presente na maior parte das toadas, algumas delas citam diretamente as torcidas organizadas, reconhecendo seu poder político e simbólico na apresentação dos boisbumbás: "Sou da galera campeã do Festival/Sou Raça Azul, sou Caprichoso/A Marujada pro meu boi

\footnotetext{
${ }^{20}$ MORAES, C.; LIMA, E.; VIANA, I. 6 x 0. In: CAPRICHOSO, Um canto de esperança para Mátria Brasilis. Disponível em: https://boicaprichoso.com/player.asp? $t=597$.

21 MAIA, E.; MAIA FILHO, E. Caprichoso: um canto novo de esperança. In: CAPRICHOSO, Um canto de esperança para Mátria Brasilis. Disponível em: https://boicaprichoso.com/player.asp?t=605.

22 KAWAKAMI, G.; BASTOS, G. Tribo Caprichoso. In: CAPRICHOSO, Um canto de esperança para Mátria Brasilis. Disponível em: https://boicaprichoso.com/player.asp?t=595.

${ }^{23}$ GÓES, F.; MOURA, M.; AGUIAR, A.; OLIVEIRA, A.; DIAS, E. Festa da liberdade. In: GARANTIDO. Nós, o povo!. Disponível em: https://www.youtube.com/watch?v=fev82q3TIG8.

${ }^{24}$ AGUIAR, A.; VALÉRIO, M.; AGUIAR, V.; MARQUES, N. Legião vermelha. In: GARANTIDO. Nós, o povo!.

Disponível em: https://www.youtube.com/watch?v=iQerraf7tll.

${ }^{25}$ KAWAKAMI, G.; BASTOS, G. Tribo Caprichoso. In: CAPRICHOSO, Um canto de esperança para Mátria
}

Brasilis. Disponível em: https://boicaprichoso.com/player.asp?t=595.

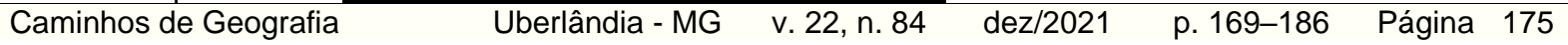


vai tocar26". Além da Raça Azul, o Caprichoso também tem outra torcida organizada: a Força Azul e Branca (FAB). O Garantido tem a Mancha Vermelha e a Louco Torcedor.

No entanto, os grupos mais citados são a Batucada (Garantido) e a Marujada (Caprichoso), que constituem a parte musical (sobretudo de percussão) de cada um dos bois-bumbás. No entanto, seus papéis dentro de cada uma das instituições extrapola a parte musical, sendo embaixadores dos bois tanto em Parintins quanto em outras cidades do Amazonas, do Norte e do Brasil, organizando eventos e promovendo os seus bumbás. Nos discursos produzidos nas toadas, o efeito de sentido mais presente é a associação da Marujada e da Batucada com o ritmo e instrumentos tradicionais do Festival de Parintins, como é possível observar nos seguintes trechos: "É tão bom/Ouvir o rufar da Marujada/Na cadência e no swing da toada/Declaro o meu amor por você27" e "Minha Batucada me faz balançar/No dois pra lá, dois pra cá28". É possível perceber um padrão do discurso no discurso de ambos os bois, associando suas baterias com a cadência, o swing e o balanço da toada e dois pra lá, dois pra cá (dança associada às toadas). Outro efeito de sentido bastante presente é a associação da Marujada e da Batucada com força/potência, com emoção e com tradição: "Sou a força do tambor da Marujada/Na cadência no compasso da toada29" e "A Batucada zabumbou na batida do meu coração ${ }^{30 "}$. No entanto, talvez o mais poderoso efeito de sentido relacionado à Batucada e à Marujada é o da fusão entre estas e a galera de seus respectivos bois. Esta fusão ilustra as estruturações identitárias fluídas, dinâmicas e híbridas típicas do paradigma da socialidade (MAFFESOLI, 2006), em que a mesma pessoa assume uma série de papéis e em que o sentimento trágico-dionisíaco funde pessoas em tribos e tribos em massas em momentos de orgiasmo. Na toada Mistura de um povo, título já sugestivo, o Caprichoso trata desta fusão de forma mais direta, dizendo "Sou da Marujada, estou na arquibancada/A balançar, arrepiar/E o som desse batuque é a mistura de um povo ${ }^{31}$ ". Já o Garantido uso de recursos discursivos mais complexos para mostrar o processo de fusão entre galera e a Batucada, demonstrando um rito de montagem dionisíaca. No início da toada, há uma separação entre "Batucada e galera perreché", mas a medida em que a toada avança e ganha força as duas se fundem em "Batucada Perreché":

Batucada e galera perreché/(Minha galera, hei, hei)/Sou Batucada tesa, invocada, toco forte sou do Norte/Pra fazer meu Brasil inteiro balançar/Meu tambor vem das tribos (hei, hei, hei, hei)/Do troar dos quilombos/É zabumba, é repente, é mistura de sons, é boi-bumbá/Faz vibrar minha galera e a arquibancada a balançar/Batucada Perreché, nós o povo de fibra e coragem/Camisa encarnada, caboclo de fé/Vou rufar meu tambor, declarar meu amor/Sou batuqueiro, Garantido, apaixonado pelo meu bumbá32.

\section{Escalas estadual e Amazônica}

Como foi possível observar, a escala local é o ponto de ancoragem dos bois-bumbás e principal referência dos seus discursos a partir das toadas. Isto ocorre por diversas razões, mas uma delas é que Parintins se confunde com o Festival Folclórico. No entanto, o Festival não se limita a Parintins não apenas em relação ao público (muitos torcedores e pessoas ativas nos bois moram em outras cidades da Amazônia, sobretudo Manaus), mas também pelas temáticas tratadas e inclusive pelas referências espaciais utilizadas. Neste sentido, o recorte que apresenta mais força é o da Amazônia, mas também há referências ao Amazonas e à Região Norte (inclusive a outros estados: "Leva o banho de cheiro que hoje eu vou preparar/Com a cajila de boto, patchuli e vindica/Leva o banho de cheiro, não deixe de levar/É o feitiço do norte de Belém do Pará/Lê, lê, lê, lê/É, é no Ver o Peso em

\footnotetext{
${ }^{26}$ MORAES, C.; LIMA, E.; VIANA, I. 6 × 0. In: CAPRICHOSO, Um canto de esperança para Mátria Brasilis. Disponível em: https://boicaprichoso.com/player.asp?t=597.

${ }^{27}$ MIRANDA, R.; NOVAES, R.; ROSENHA. A vida me fez Caprichoso. In: CAPRICHOSO, Um canto de esperança para Mátria Brasilis. Disponível em: https://boicaprichoso.com/player.asp?t=598.

${ }^{28}$ ANSELMO, J.; BULCÃO, B.; GADELHA, R.; ANSELMO, N. Meu nome é povão. In: GARANTIDO. Nós, o povo!. Disponível em: https://www.youtube.com/watch?v=ZUhKc02ihr8.

${ }^{29} \mathrm{BELO}$; CIDADE, A. O mais belo de Parintins. In: CAPRICHOSO, Um canto de esperança para Mátria Brasilis. Disponível em: https://boicaprichoso.com/player.asp?t=601.

${ }^{30}$ DIAS, E.; MOURA, M.; KENNEDY, J. Viva São João. In: GARANTIDO. Nós, o povo!. Disponível em: https://www.youtube.com/watch?v=pr8zExz2X-M.

${ }^{31}$ ASSAYAG, R. PANTOJA, L. Mistura de um povo. In: CAPRICHOSO, Um canto de esperança para Mátria Brasilis. Disponível em: https://boicaprichoso.com/player.asp?t=599.

${ }^{32}$ HAIDOS, D.; ALVINO, V. Batucada perreché. In: GARANTIDO. Nós, o povo!. Disponível em: https://www.youtube.com/watch?v=KAw5H5rfiXg.
} 
Belém do Pará"33). Para Cavalcanti (2000), a Amazônia não é apenas o pano de fundo, mas o que torna o Festival original e capaz de se comunicar com todo o Brasil.

A Amazônia aparece como referência temática, já que o próprio auto do boi - representação que é a base das festas de boi de todo o Brasil e de diversos locais da Europa - foi adaptada na Amazônia a partir de elementos e referências da região (CAVALCANTI, 2000; SILVA, 2009). O caso mais emblemático é a participação direta do pajé na ressuscitação do boi, que em outros atos é ressuscitado por outras figuras, como padre e médico. No entanto, a Amazônia também aparece como referência de recorte espacial, associada ao universo simbólico retratado pelos bois-bumbás: "Brilha em Parintins uma festa com a cara da gente/[...]/O maior São João da Amazônia/Mostramos para o mundo ver ${ }^{34 "}$ e "Rainha do meu boi/Traz a Amazônia (Mundurukania)35". No trecho da toada do Garantido, a Amazônia é um recorte espacial de construção recente, ligado à Amazônia brasileira, já que o boi compara o Festival de Parintins com demais festas de São João da região - é bastante comum comparar o Festival com o Carnaval do Rio de Janeiro, mas concordamos com Cavalcanti (2000), quando demonstra que trata-se de uma festa junina, não só pelo período, mas por estar inserida em um circuito de religiosidade. Já no discurso da toada do Caprichoso, a Amazônia aparece como um recorte indígena ancestral, associada a terra dos índios mundurukus (a Mundurukânia).

A referência indígena e cabocla é uma constante na formação discursiva de ambos os bois-bumbás, não apenas nas toadas mas em toda sua apresentação no bumbódromo. Isto se intensificou na década de 1990 e se tornou uma marca do Festival de Parintins (SILVA, 2009; SILVA, 2011; SENA; MAISEL, 2019). Outras figuras que são constantemente utilizadas, mas em menor frequência, são o negro e o nordestino, como parte da formação do povo da Amazônia. Heróis do Brasil, do Caprichoso, é um bom exemplo do discurso dos bois sobre a Amazônia e das figuras a ela associadas:

\begin{abstract}
Neste solo sagrado com os pés no chão/Vem o caboclo a caminhar/De um sonho perdido/Um desejo incontido/Em busca de um Brasil melhor/Gente de esperança/Olhar confuso e desafios/Despertai ó mátria amada!/Sou caboclo herói do Brasil/O meu sangue é de guerreiro/De valente, sou do mato/Sou caboclo, eu sou consagrado/Sou da tribo Caprichoso/Sou guerreiro encantado/De terreiro brasileiro/Sou nortista cancioneiro/ Amazônia/Sou negro, sou índio, sou maracatu/Dança de terreiro, sou bumba meu boi/Sou tribo riqueza da minha nação/Sou arte, cultura dessa tradição/Caboclo afro-brasileiro eu sou raiz/Heróis do Brasil/[...]/Eu trago um pouco de todos em mim/Sou caboclo de Parintins/Heróis do Brasil/Em busca de um Brasil melhor vou singrando meu destino. Desistir jamais, pois em minhas veias corre o sangue de meus antepassados. Sou mestiço, cafuzo, negro, sou índio, trago um pouco de todos em mim, sou caboclo de Parintins, somos heróis do $\mathrm{Brasi}^{36}$
\end{abstract}

$\mathrm{Na}$ toada, a Amazônia é referida como "solo sagrado", revelando um efeito de sentido bastante presente nas toadas de ambos os bois, a de uma Amazônia real retratada pelos bois, mesmo com contornos espetaculares e idealizados, construída no plano discursivo (SILVA, 2009). Outra figura idealizada é o caboclo, tido, na toada, como "herói do Brasil". Ele é comumente associado a um defensor da Amazônia, a um lutador e a um trabalhador justo, como ocorre na toada supracitada do Caprichoso e na toada Caboclitude, do Garantido: "Caboclo nato/Não é só quem mora no mato/É aquele que resiste no Sol/São tantas lutas/Não há lugar nesse torrão/que faz mudar seu coração/[...]/Pescador de sonhos/Artesão da vida37". Fiori e Rodrigues (2014) leem o próprio Festival como "um ícone de identidade cabocla, mestiça, amazônica e amazônida, ou seja, de uma brasilidade para além das representações comumente produzidas no sudeste". Tal sobreposição de identidades vai de encontro com as identidades pós-modernas (HALL, 2005), mas não fecham a possibilidade de construção de identidades em outras escalas, inclusive a partir de elementos de

${ }^{33}$ LEVY, H.; NEVES, I.; MORENO, M. Erveiras da Amazônia. In: GARANTIDO. Nós, o povo!. Disponível em: https://www.youtube.com/watch?v=-nCde15NwJQ\&pbjreload=10.

${ }^{34}$ DIAS, E.; MOURA, M.; KENNEDY, J. Viva São João. In: GARANTIDO. Nós, o povo!. Disponível em: https://www.youtube.com/watch?v=pr8zExz2X-M.

${ }^{35}$ DÚ SAGRADO, P.; MEDEIROS, A. Rainha do povo azulado. In: CAPRICHOSO, Um canto de esperança para Mátria Brasilis. Disponível em: https://boicaprichoso.com/player.asp?t=596.

${ }^{36}$ NASCIMENTO, R.; COLARES, M.; AZEVEDO, F. Heróis do Brasil. In: CAPRICHOSO, Um canto de esperança para Mátria Brasilis. Disponível em: https://boicaprichoso.com/player.asp?t=603.

${ }^{37}$ MARUPIARA, R.; ALVES, R.; KIMURA, A.; CRUZ, N. Caboclitude. In: GARANTIDO. Nós, o povo!. Disponível em: https://www.youtube.com/watch?v=W-Pg-jJ8fkk.

$\begin{array}{llllll}\text { Caminhos de Geografia } & \text { Uberlândia - MG } & \text { v. 22, n. } 84 & \text { dez/2021 } & \text { p. 169-186 } & \text { Página } 177\end{array}$


outras regiões. Este é o caso da toada do Caprichoso, em que aparecem os recortes espaciais Região Norte ("sou nortista") e Região Nordeste (com seus elementos típicos, como o maracatu e bumba-meu-boi), além do Brasil e Parintins. Percebe-se, portanto, a construção discursiva de multiterritorialidades que articulam o local ("caboclo de Parintins") com o nacional ("herói do Brasil"), passando por elementos identitários ligados à cultural popular (nortista e nordestina, em um híbrido próprio de Parintins) e à origem ("Sou mestiço, cafuzo, negro, sou índio, trago um pouco de todos em mim" e "em minhas veias corre o sangue dos meus antepassados"). Tais multiterritorialidades não estão presentes apenas no campo discursivo, mas se baseiam em estruturações identitárias da vida cotidiana de Parintins, que também são alimentadas pelas representações sociais produzidas a partir dos discursos das toadas e de outras formas discursivas do Festival.

O índio também é fortemente associado à proteção da floresta e, assim como o caboclo, está imerso em uma mitologia cheia de ritos e entidades fantásticas ligadas à floresta amazônica. No entanto, apesar de figura de resistência, o índio também é constantemente utilizado para simbolizar um grupo que sofre com a destruição de seu lugar, de seu modo de vida e de seu universo simbólico: "Ouça o choro do índio que ecoa/No canto caboclo que clama/Pela floresta que um dia foi seu lar/Sua virgem verde casa desnudada/Sua lenda, sua tribo, seu rito desapareceu/Sua história, sua mátria brasilis desapareceu" e a toada continua mostrando a causa e uma esperança: "E a cobra grande já sumiu/Não sei quem viu mapinguari/O homem branco explorou o índio valente/Consumindo a sua fé/Até que chegou o meu boi/Trazendo a seu povo/Um canto novo de esperança/Caprichoso!38". Em oposição ao índio está a figura do homem branco - que simboliza a ideia de progresso associado à destruição da floresta amazônica (e consequentemente de seu povo). Porém, há toadas que também mostram o branco como uma das figuras que confere a diversidade própria de Parintins e da Amazônia. A celebração desta diversidade se dá pelo deslocamento da afirmação de identidades ribeirinhas para identidades amazônicas (FURNALETTO, 2011).

No entanto, quando o homem branco aparece sozinho, geralmente, traz um efeito de sentido negativo. Em compensação, o boi-bumbá, associado à proteção da floresta e à preservação da cultura popular, é a figura de esperança, da construção de uma nova Amazônia e de um novo Brasil, de montagem pós-moderna, conectados a valores arcaicos (MAFFESOLI, 2006).

\section{Escala nacional}

Os efeitos de sentido que utilizam a escala nacional como referência são bastante diversos, mas podemos destacar três: o dos bois-bumbás pertencentes (e representantes) ao Brasil; a dos boisbumbás convidando os turistas brasileiros para brincar no Festival (aqui o enunciatário são aqueles que vêm de fora); e a dos bois-bumbás como representantes da cultura nacional (evocando elementos desta, sobretudo, nordestina e criando representações do índio como figura nacional). É comum, no entanto, que estes efeitos de sentido se misturem na formação discursiva dos bois. Um exemplo de múltiplos efeitos de sentido está na seguinte toada:

É nativo da Mátria Brasilis/Todo mundo vai vir festejar/É toada é festança brasileira/Vem pra cá! É boi-bumbá/[...]/Vem me ver em Parintins/Vem brincar boibumbá no touro brasileiro/Vem revolucionar, vem meu povo festeiro/Caprichoso convida o país/Pra brincar no boi de Parintins/O importante é o Brasil que a gente inventa aqui ${ }^{39}$

Nesta toada, o Caprichoso se coloca como um boi brasileiro ("é nativo da Mátria Brasilis" e "touro brasileiro"), mas também como o "boi de Parintins". Neste jogo de identidades híbridas multiescalares, - Caprichoso se desterritorializa de Parintins para se reterritorializar em escala nacional. Porém, novamente se reterritorializa em escala local para convidar o visitante (um outro, que é brasileiro, mas não é brasileiro de Parintins) para brincar de boi-bumbá, o que fica evidente pelo uso do "vem" ("vem me ver em Parintins", "vem povo festeiro"). O Garantido usa elementos discursivo muito parecidos com os do Caprichoso, na toada Nós, o Povo! alternando entre o "nós" (Garantido como brasileiro) e o "você" (convidando o outro): "Vem, meu Brasil/Pinta a cara de vermelho/Nosso povo brasileiro/Se apresenta na festa do meu boi-bumbá/É, nossa arte é guerreira/[...]/Do amado chão brasileiro/[...]/O

\footnotetext{
${ }^{38}$ MAIA, E.; MAIA FILHO, E. Caprichoso: um canto novo de esperança. In: CAPRICHOSO, Um canto de esperança para Mátria Brasilis. Disponível em: https://boicaprichoso.com/player.asp?t=605.

${ }^{39}$ BASTOS, G.; KAWAKAMI, G. Um canto de esperança para Mátria Brasilis. In: CAPRICHOSO, Um canto de esperança para Mátria Brasilis. Disponível em: https://boicaprichoso.com/player.asp?t=593.

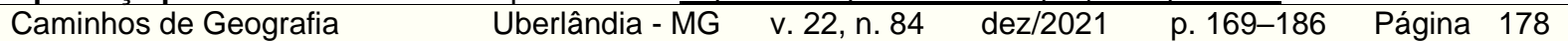


povo festeiro, orgulhoso e bravio/E nessa mistura meu nome é Brasil40". Mas em outra toada, o Garantido é mais direto quando canta: "Boa noite/Pra quem veio de tão longe!41". O "tão longe" reforça a representação social de isolamento de Parintins do restante do Brasil, promovido muito mais pela distância física do que a simbólico-cultural. No entanto, também carrega o efeito de sentido de respeito ao turista, que fez um esforço para chegar até Parintins especialmente para brincar no Festival (e principalmente, ver o Garantido).

Por outro lado, o Garantido também produz o efeito de sentido de que a festa é nacional e de que domina simbolicamente o país (através de sua rainha do folclore): "Rainha do folclore, do povo ela vem, do povo ela vem, o Brasil é teu reinado, chegou pra reinar ${ }^{42 "}$. O Caprichoso também usa a mesma figura para demonstrar sua brasilidade: "Traz contigo a força da mátria amada/[...]/Filha de um país de bravos ${ }^{43 "}$.

Apesar do discurso de exaltação do Brasil (sobretudo na dimensão cultural) ser bastante comum, há toadas que apresentam críticas à apropriação do Brasil por determinados projetos que vão de encontro aos ideais defendidos pelos bois. Em 2020, o Caprichoso apresentou toadas que realizam críticas, como o incêndio simbólico do Brasil ("'Fogo-real' já consumiu/As cores do meu Brasil") e exploração do país: "É o Brasil! Mãe negada/Mátria viva explorada/Terra forte açoitada/Pietá destronada/É o Brasil! Misturado/Pindorama loteado/Cativeiro mascarado/De contraste camuflado". No entanto, em ambas as toadas, respectivamente, o Caprichoso preserva o efeito de sentido otimista: "amanhã/que já vai chegar/canta mátria mãe/esperança meu sonho azul44" e "É o Brasil! Cancioneiro/Que se faz luzeiro/Bradando a arte do povo/Que ecoa em canto novo/O Brasil que a gente quer reinventar! $45 "$.

Em seu tema de 2020, Nós, o Povo!, o Garantido também rompeu com o padrão discursivo ao apresentar diversas figuras como constituintes do povo brasileiro. Na toada homônima, o Garantido cita figuras anônimas - como Pedro, José e Zenaide -, em meio a referências locais e regionais como Davi Kopenawa, Verequete e Lindolfo Monteverde - e de figuras conhecidas nacionalmente tanto antigas como Dandara dos Palmares, Tia Ciata e Mário de Andrade quanto recentes, como as brutalmente assassinadas Dorothy Stang e Marielle Franco:

Pedro, pescador/Zenaide, professora/Davi Kopenawa, cacique/Mário de Andrade, folclorista/Dorothy, missionária/Edson Luís, estudante/Vavazinho, poeta/Dandara, quilombola/José, operário/Mestre Bimba, capoeira/ Benedita, mãe-de-santo/Jorge Amado, escritor/Verequete, peixeiro/ Marielle, feminista/Tia Ciata, sambista/Lindolfo Monteverde, criador do Boi Garantido/Nós, o povo!46.

Mantendo uma tradição da formação discursiva das toadas de ambos os bumbás, grande parte das referências culturais citadas na toada do Garantido são nordestinas, como Dandara dos Palmares, Mestre Bimba e Jorge Amado. No entanto, as referências nordestinas - ligadas aos processos migratórios para a Amazônia e à própria criação dos bois Caprichoso e Garantido (SILVA, 2009; SILVA, 2011) - mas comuns estão relacionadas ao bumba-meu-boi (e demais referências à brincadeira de boi típica do Maranhão) e a ritmos do Nordeste. Isto pode ser observado nos seguintes trechos: "Na luz da minha fé, Parintins virou congá/É axé, é Caprichoso é patuá, juremá!47" e "Tradição do velho mundo, reinventada nesse chão/[...]/Tem forró, boi-bumbá, xote, xaxado, baião/A batucada zabumbou na batida do meu coração/A sanfona acompanhou a pegada do Gonzagão48". $O$

\footnotetext{
${ }^{40}$ DIAS, E.; MOURA, M.; KENNEDY, J.; AGUIAR, A. Nós, o povo! In: GARANTIDO. Nós, o povo!. Disponível em: https://www.youtube.com/watch?v=H5vEey-6d9c.

${ }^{41}$ DIAS, E.; MOURA, M.; KENNEDY, J.; AGUIAR, A. Boi brinquedo de amor. In: GARANTIDO. Nós, o povo!. Disponível em: https://www.youtube.com/watch?v=roPblg2xKFc.

${ }^{42}$ DIAS, E.; MOURA, M.; KENNEDY, J.; AGUIAR, A. Realeza popular. In: GARANTIDO. Nós, o povo!. Disponível em: https://www.youtube.com/watch?v=C9IY0Fnryko.

${ }^{43}$ DÚ SAGRADO, P.; MEDEIROS, A. Rainha do povo azulado. In: CAPRICHOSO, Um canto de esperança para Mátria Brasilis. Disponível em: https://boicaprichoso.com/player.asp?t=596.

${ }^{44}$ DÚ SAGRADO, P. Mátria. In: CAPRICHOSO, Um canto de esperança para Mátria Brasilis. Disponível em: https://boicaprichoso.com/player.asp?t=609.

45BASTOS, G.; KAWAKAMI, G. Um canto de esperança para Mátria Brasilis. In: CAPRICHOSO, Um canto de esperança para Mátria Brasilis. Disponível em: https://boicaprichoso.com/player.asp?t=593.

${ }^{46}$ DIAS, E.; MOURA, M.; KENNEDY, J.; AGUIAR, A. Nós, o povo! In: GARANTIDO. Nós, o povo!. Disponível em: https://www.youtube.com/watch?v=H5vEey-6d9c.

${ }^{47}$ NAKANOMI, E.; BARBOSA, R.; BARBOSA JR., R. Boi de encantaria. In: CAPRICHOSO, Um canto de esperança para Mátria Brasilis. Disponível em: https://boicaprichoso.com/player.asp?t=604.

${ }^{48}$ DIAS, E.; MOURA, M.; KENNEDY, J. Viva São João. In: GARANTIDO. Nós, o povo!. Disponível em: https://www.youtube.com/watch?v=pr8zExz2X-M.
} 
efeito de sentido da valorização da cultura nordestina não apenas está ligado a uma autohomenagem (aos bois e ao povo parintinense/amazonense), mas também à legitimação dos boibumbás e do Festival como manifestações culturais/folclóricas que possuem ancestralidades em comum com outras manifestações há mais tempo reconhecidas como legitimamente brasileiras, bem como mantém relações atualmente com estas - o que se dá pelo hibridismo, inclusive de ritmos encontrados nas toadas.

Neste sentido, o índio funciona ao mesmo tempo como figura que distingue o folclore parintinense e como elemento que cria uma unidade discursiva e simbólica com o Brasil, pois em muitas vezes o índio é citado como uma figura local/regional, mas em várias outras como uma figura nacional. Isto é possível de ser observado na toada Dança dos tuxauas, do Caprichoso: "Entrem na ocara sagrada/Na arena da festa/Recontam histórias/De heróis tribais do meu Brasil/[...]/Exalta a floresta/É o templo ancestral do meu país ${ }^{49}$. Percebe-se a construção/reforço da ideia do índio como herói nacional e também da floresta como espaço sagrado. O heroísmo indígena é também celebrado nas toadas que contam ritos e mitologias de diferentes tribos, cujos nomes também são citados em várias outras toadas. No entanto, outro discurso relacionado aos indígenas, como já vimos anteriormente, é o da resistência e o da denúncia os males causados pela exploração da Amazônia (SILVA, 2009; SILVA, 2011). Este discurso também é utilizado para demonstrar a espacialização dos indígenas como povos do Brasil (e não apenas da Amazônia), que buscam atualmente seus direitos: "Minha voz entoa a resistência/Dos povos indígenas do Brasil/Dizimados, convertidos ou civilizados/Perseverantes na luta pelo direito à terra ${ }^{50 "}$.

\section{Escala global}

Agrupamos na escala global todos os discursos que têm como referência ou enunciatário o mundo, mas também incluímos os discursos com temas globais, tais como a religiosidade, as pautas ambientais, feministas e de direitos humanos. O discurso em favor do meio ambiente é uma constante nas toadas e apresentações de ambos os bois ano após ano. Em 2020, destacamos duas toadas do Caprichoso: "Caprichoso!/Balança e rodopia na evolução/Traz no estandarte a bandeira da preservação/A paz na mata é um apelo que fazemos numa forma de canção ${ }^{51 "}$ e "Um novo tempo virá/A humanidade entenderá/Tudo é preciso, pra se preservar/Os saberes dos livros na terra/A serra que encerra/Gafanhotos de ferro na floresta/É pra devorar, pra gananciar/A riqueza, os valores que há/O medo que impera/Está em toda selva52". A formação discursiva das toadas do boi tiram a Amazônia do lugar de pano de fundo, de palco da festa e a coloca como uma temática própria, cuja preservação se tornou uma bandeira do Festival (SILVA, 2009; SILVA, 2011).

Além do discurso ambientalista, um efeito de sentido bastante comum - e que ganhou força a partir da década de 1990, quando algumas toadas, principalmente Vermelho se tornaram nacional e internacionalmente conhecidas, é a do Festival como festa global. Este efeito de sentido está associado a um discurso que tem como enunciatário o turista, mas também a um discurso que ignora qualquer tipo de barreira ou fronteira para as toadas, para os bois e para o Festival, reterritorializando a Festa na escala global: "O som dos tambores ecoam na mata/Anunciando pro mundo, a festa do meu boi-bumbá53". Aqui, o anúncio é escutado pelo mundo todo independentemente do idioma, pois o som dos tambores é uma linguagem universal. Em "Meu boi é destaque, o mundo vem pra cá54", o discurso indica que o Garantido é capaz de atrair turistas do mundo todo e em "Caprichoso!/A estrela

\footnotetext{
${ }^{49}$ NASCIMENTO, R.; COLARES, M.; AZEVEDO, Dança dos Tuxauas. In: CAPRICHOSO, Um canto de esperança para Mátria Brasilis. Disponível em: https://boicaprichoso.com/player.asp? $t=612$. 50PANTOJA, G.; KENNEDY, J.; DIAS, E. Peles vermelhas do Brasil. In: GARANTIDO. Nós, o povo!. Disponível em: https://www.youtube.com/watch?v=LPaeAMWdF0o.

${ }^{51}$ MAIA, E.; MAIA FILHO, E. Caprichoso: um canto novo de esperança. In: CAPRICHOSO, Um canto de esperança para Mátria Brasilis. Disponível em: https://boicaprichoso.com/player.asp?t=605.

${ }^{52}$ DÚ SAGRADO, P. Mátria. In: CAPRICHOSO, Um canto de esperança para Mátria Brasilis. Disponível em: https://boicaprichoso.com/player.asp?t=609.

53KAWAKAMI, G.; BASTOS, G. Tribo Caprichoso. In: CAPRICHOSO, Um canto de esperança para Mátria

Brasilis. Disponível em: https://boicaprichoso.com/player.asp?t=595.

${ }^{54}$ DIAS, E.; MOURA, M.; KENNEDY, J.; AGUIAR, A. Nós, o povo! In: GARANTIDO. Nós, o povo!. Disponível em: https://www.youtube.com/watch?v=H5vEey-6d9c.

\begin{tabular}{llllll}
\hline Caminhos de Geografia & Uberlândia - MG & v. 22, n. 84 & dez/2021 & p. 169-186 Página 180
\end{tabular}
}


conquistou o coração/Do caboclo e do povo de além-mar55", é possível verificar a expansão da territorialidade do boi - pelo menos no plano discursivo - para outros continentes.

Um efeito de sentido parecido com aquele produzido pelo discurso de valorização da cultura e referências nordestinas também aparece na escala global. A identificação dos bois com a África (e a cultura afro) e com a América Latina também se manifesta como celebração da ancestralidade, como é possível perceber na toada Nós, o Povo!: "Com a Mãe África no tambor/Meu coração ameríndio pulsou/Quebrei correntes com fé e coragem/Meu canto liberto é diversidade ${ }^{56 "}$.

A diversidade, mencionada na toada do Garantido é um tema que vem crescendo nos últimos anos no discurso dos bois. Passou de apenas diversidade cultural e racial e se expandiu para outras pautas de diversidade, como contra o machismo e a homofobia, como é possível observar a toada em homenagem a São Jorge, do Caprichoso: "Santo de terreiro, santo brasileiro/Que aqui na terra trava uma batalha/Tão difícil, tão atroz/Contra intolerância, contra o desrespeito/Contra a miséria, contra o preconceito/Contra o genocídio e feminicídio/Corrupção, racismo e qualquer distinção de cor ${ }^{57 "}$. É possível, portanto, observar a incorporação de temáticas pautadas pela vida cotidiana brasileira, ampliando a dimensão e a abrangência da arte produzida em Parintins.

Uma destes temas que perpassou diversas toadas de ambos os bois foi o feminismo. No Caprichoso o discurso feminista esteve presente inclusive na temática Mátria, um neologismo consagrado por Caetano Veloso a fim de opor o sexismo que carrega a palavra pátria (derivada de pai, patriarca). 0 discurso feminista do Caprichoso permeia várias toadas (inclusive pelos seus nomes, como Matriarca, Mátria, Um canto de esperança à Mátria Brasilis e Meu Deus é Maria), seja pela valorização de figuras femininas ("Me encorajou a dar os primeiros passos/Na vida pra ser o que sou/[...]/Luz da minha vida/[...] Seu coração é uma casa/De portas abertas/De ternura e paixão/[...]/Mãe, luz do mundo/Mãe, mel da vida/Mãe, matriarca/Minha estrela amada! ${ }^{58 ")}$ seja por alusões mais diretas às lutas feministas ("Contra o genocídio e feminicídio59"). No entanto, mesmo não tendo o feminismo como seu fio condutor temático, é o Boi Garantido que toca de maneira mais direta na temática, na toada Rosas Vermelhas:

\begin{abstract}
Vou tomar banho de cheiro/Com aroma de emancipação/O perfume das Rosas Vermelhas/Mulheres guerreiras da minha nação/Provedoras da esperança/Cuidadoras da transformação/Rosa-choque misturado/Ao vermelho do meu coração/Escute com muita atenção, outros desejos de Catirina/São os mesmos de minha mãe, minha irmã e minha filha/Pelo fim da violência, do machismo e da homofobia/São desejos de Dandaras, Marielles e Marias/Venham sempre com as outras/Que os outros vão respeitar/Rosas do jardim do meu Brasil/Rosas Vermelhas do meu boi-bumbá/Vou cantar essa vontade/Com a força da arte que luta/Pela igualdade de gênero/Que é necessária, urgente e justa/Rosas caboclas, negras rosas/Rosas das matas, índias rosas/Rosas vermelhas, guerreiras/Do povo Garantido 60 .
\end{abstract}

Novamente, o Garantido lança mão do recurso discursivo de mencionar referências, como Marielle Franco e Dandara dos Palmares (ambas no plural para designar o heroísmo feminino), além de Maria (que pode ser interpretada como a figura bíblica, mas também como um nome genérico às mulheres). Também menciona Mãe Catirina, figura central no auto do boi, fazendo uma brincadeira com o termo desejo, já que na mitologia do boi foi um desejo de gravidez de Catirina que levou Pai Francisco matar o boi. Para tal, o Garantido usa o termo outros desejos, para designar as pautas que unem as mulheres ("minha mãe, minha irmã e minha filha").

\footnotetext{
${ }^{55}$ MAIA, E.; MAIA FILHO, E. Caprichoso: um canto novo de esperança. In: CAPRICHOSO, Um canto de esperança para Mátria Brasilis. Disponível em: https://boicaprichoso.com/player.asp? $t=605$.

${ }^{56}$ DIAS, E.; MOURA, M.; KENNEDY, J.; AGUIAR, A. Nós, o povo! In: GARANTIDO. Nós, o povo!. Disponível em: https://www.youtube.com/watch?v=H5vEey-6d9c.

${ }^{57}$ PANTOJA, L. NAKANOME, E. Armadura de fé. In: CAPRICHOSO, Um canto de esperança para Mátria Brasilis. Disponível em: https://boicaprichoso.com/player.asp?t=618.

58MORAES, C.; SILVA, D.; SANTOS, S. Matriarca. In: CAPRICHOSO, Um canto de esperança para Mátria Brasilis. Disponível em: https://boicaprichoso.com/player.asp?t=606.

${ }^{59}$ PANTOJA, L. NAKANOME, E. Armadura de fé. In: CAPRICHOSO, Um canto de esperança para Mátria Brasilis. Disponível em: https://boicaprichoso.com/player.asp?t=618.

${ }^{60}$ DIAS, E.; MOURA, M.; KENNEDY, J. Rosas vermelhas. In: GARANTIDO. Nós, o povo!. Disponível em: https://www.youtube.com/watch?v=RxPkKWDt5DE.

\begin{tabular}{llllll}
\hline Caminhos de Geografia & Uberlândia - MG & v. 22, n. 84 & dez/2021 & p. 169-186 Página 181
\end{tabular}
}


Se o discurso do Garantido é o mais direto pelo "fim da violência, do machismo e da homofobia" e "pela igualdade de gênero", a toada Meu Deus é Maria, do Caprichoso, é a mais ousada, pois mistura feminismo e religiosidade, tema tão caro e tradicional nas toadas de ambos os bois:

Princesas e rainhas/Palacetes sinfonias, histórias/Se foi merecido agora é sua vez/Vem lançar o teu canto de amor/Ascender com bravura do chão/Se levanta em uníssono/Maria é o deus dessa nação/Maria sou eu, Maria é tua mãe/Maria é tua avó, tuas irmãs/Maria mulher, Maria enrustida/Maria menino ou Maria menina/Maria família, Maria vizinha/Maria da fé, dos mil dons de milagre/Ai Maria meu Deus! Meu Deus!/Meu Deus! É Maria/Viva Maria beleza divina ${ }^{61}$

A toada é cantada por uma mulher, o que não é comum na tradição dos bois, já que os levantadores de toada oficiais sempre foram homens. Assim, encontramos não apenas uma inovação no conteúdo do discurso, mas também de enunciador. É uma mulher falando de feminismo (Rosas Vermelhas, do Garantido, também é cantada por uma mulher, mas dividindo os vocais com o levantador de toadas oficial). É uma mulher cantando toada (o que tem ocorrido esporadicamente nos últimos anos), o que automaticamente questiona o porquê disto não ser mais comum. Silva (2011) destaca o aumento da presença feminina no Festival, mas em 2020 apenas seis toadas tinham mulheres entre seus compositores, nunca como a principal). No entanto, Brito, Ribeiro e Souza (2017, p. 20) apontam que as atividades de comando nos bois são exercidas por elementos masculinos e os funcionários formais também são homens, cabendo às mulheres "atividades subalternas e 'femininas' na parte operacional da costura, adereços e chapéus". Outro ponto que merece destaque na toada do Caprichoso é a ampliação da noção do feminino, mencionando "Maria menino" e corroborando, assim, com a noção de identidade pós-moderna (HALL, 2005).

Mesmo com todas estas inovações, o discurso de religiosidade - sobretudo ligado à fé católica - se mantém fortemente presente em toadas de ambos os bois, pois a "a festa nasceu e cresceu encontrando sua validação na fonte religiosa ligada ao catolicismo popular" (SILVA, 2011, p. 237) e esta religiosidade está na própria base da tradição das brincadeiras de boi em diversos locais (SILVA, 2010). Em 2020, a religiosidade esteve presente em ao menos cinco toadas de cada um dos bois. O discurso de religiosidade aparece de forma pontual, em meio de toadas com temáticas variadas, mas também aparece em toadas específicas.

No primeiro caso, é comum o efeito de sentido que reforça a origem dos bois como promessa a santos: "Meu boi é de encanto, promessa de santo ${ }^{62 " ~ e ~ " U m ~ b o i ~ d e ~ p r o m e s s a, ~ o ~ m a i s ~ c a m p e a ̃ o ~ d o ~}$ lugar63". Outro efeito de sentido bastante presente é o do caboclo ou do parintinense como povo de fé: "Gente panema, gente de reza/Gente de sonho, gente de prece64" e "Reza o terço e faz seu pedido/À Virgem do Carmo/Pra fazer o meu boi campeão65". Observa-se além da manifestação da associação do povo com a fé, que o efeito de sentido produzido é de igualar a importância da fé com a importância do boi e relacionar as duas dimensões principais da vida cotidiana dos parintinenses.

A religiosidade é também fundida com elementos e crenças da cultura local, bem como a manifestação religiosa católica é sincretizada com outras religiões. O Garantido associa o processo de cura por ervas (elemento local) com a fé católica: "Tudo cura essas ervas benditas/Mas não basta só querer/Tem que ter muita fé/Nos encantos da Amazônia e na Virgem de Nazaré66“. Também apresenta o sincretismo religioso entre o catolicismo (São João) com o candomblé (Xangô): "Viva São João/ Junho festeiro, dançante, colorido e sonhador/Da fartura e da colheita, mês do menino Xangô/Ao Batista de Jesus, cantos e rezas de gratidão67". O mesmo é feito pelo Caprichoso em relação a São Jorge (Oxóssi e Ogum): "Oxóssi das matas, meu Ogum é de guerra/Cavaleiro da flor,

\footnotetext{
${ }^{61}$ BARBOSA JR., R. Meu Deus é Maria. In: CAPRICHOSO, Um canto de esperança para Mátria Brasilis. Disponível em: https://boicaprichoso.com/player.asp?t=615.

62BASTOS, G.; KAWAKAMI, G. Um canto de esperança para Mátria Brasilis. In: CAPRICHOSO, Um canto de esperança para Mátria Brasilis. Disponível em: https://boicaprichoso.com/player.asp? $t=593$.

${ }^{63}$ DIAS, E.; MOURA, M.; KENNEDY, J. Viva São João. In: GARANTIDO. Nós, o povo!. Disponível em: https://www.youtube.com/watch?v=pr8zExz2X-M.

64MARUPIARA, R.; ALVES, R.; KIMURA, A.; CRUZ, N. Caboclitude. In: GARANTIDO. Nós, o povo!. Disponível em: https://www.youtube.com/watch?v=W-Pg-jJ8fkk.

${ }^{65}$ MORAES, C.; SILVA, D.; SANTOS, S. Matriarca. In: CAPRICHOSO, Um canto de esperança para Mátria Brasilis. Disponível em: https://boicaprichoso.com/player.asp?t=606.

${ }^{66}$ LEVY, H.; NEVES, I.; MORENO, M. Erveiras da Amazônia. In: GARANTIDO. Nós, o povo!. Disponível em: https://www.youtube.com/watch? $v=-n C d e 15 N w J Q \&$ pbjreload=10.

${ }^{67}$ DIAS, E.; MOURA, M.; KENNEDY, J. Viva São João. In: GARANTIDO. Nós, o povo!. Disponível em: https://www.youtube.com/watch?v=pr8zExz2X-M. 
São Jorge protetor68". A toada Armadura de fé também é aquela que mais claramente se enquadra como uma toada específica sobre religiosidade, já que faz uma homenagem a São Jorge, contendo trechos de sua oração:

Oh São Jorge, meu santo guerreiro/Que trazeis em vosso rosto a esperança/Abre meus caminhos/Eu andarei vestido e armado com vossas armas/Para que meus inimigos/Tendo pés não me alcancem/Tendo mãos não me peguem/Tendo olhos não me enxerguem/E nem pensamentos tenham para me fazerem mal/Armas de fogo o meu corpo não alcançarão/Facas e lanças se arrebentarão/Sem o meu corpo amarrar/Glorioso São Jorge, em nome de Deus/Estendei vosso escudo e vossas poderosas armas/Fortalecei minha fé/E defenda os guerreiros do boi Caprichoso/Okearó Oxóssi, Patakuri Ogunhê Ogum! ${ }^{69}$.

\section{CONSIDERAÇÕES FINAIS}

Pudemos perceber, pela análise das toadas, que questão da identidade é um elemento central na sua composição, em seus efeitos de sentido e nas possíveis representações sociais que produzem. As toadas não são o único elemento discursivo dos quais os bois lançam mão para criar, reforçar e ressignificar sua ligação com Parintins, com seus bairros, com seus torcedores, com o Amazonas, com a Amazônia, com a cultural brasileira, com o Brasil ou com o mundo. No entanto, são provavelmente o mais poderoso deles, pois além de terem grande força discursiva, misturando letra e ritmo (elemento que não nos propusemos analisar diretamente), ficam gravadas e podem ser escutadas mesmo em períodos além do Festival e em locais fora de Parintins. Desta forma, possuem multiterritorialidades não apenas no conteúdo, mas também na forma, carregando marcas de uma festa, que segundo Claval (2009), mudou de escala, não sendo mais apenas local ou regional.

No entanto, as toadas mantêm seu caráter proxêmico (MAFFESOLI, 2004), sendo um dos seus principais efeitos de sentido a aglutinação em torno dos bois, bem como a valorização dos elementos típicos locais ou regionais (o que se pode observar pela exaltação da cultura indígena e cabocla). São também responsáveis pela criação e perduração de momentos de presença (SHIELDS, 1999; LEFEBVRE, 2006), que rompem com a vida cotidiana, mas que, a partir da leitura do espaço diferencial (LEFEBVRE, 1991), estão presentes no próprio cotidiano de Parintins. Mesmo assim, os visitantes se configuram como importantes enunciatários das toadas, sendo não apenas convidados, mas legitimadores do Festival como tipicamente brasileiro, amazônico e, inclusive, global. Através das toadas os bois se colocam como representantes da Amazônia, sua cultura e preservação, sendo legitimados pela população local/regional mas também pelos visitantes (ou aqueles de fora, que consomem as toadas como produto cultural).

Deste modo, podemos inferir que os discursos contidos nas toadas são múltiplos em efeitos de sentido (apesar de uma coerência discursiva entre as toadas do mesmo ano e também com as toadas de anos anteriores, apesar de algumas inovações serem observadas), mas também são múltiplos em enunciatários. Tanto os efeitos de sentido quanto os enunciatários múltiplos podem ser considerados multiterritoriais, pois há uma forte articulação entre diferentes escalas em um jogo de estruturações identitárias construídas, apropriadas e representadas. Esta multiterritorialidade presente nos discursos (e, posteriormente nas representações sociais geradas a partir) das toadas não ocorre apenas pela menção de diferentes territórios ou escalas nas letras (como Parintins, Amazonas, Amazônia, Brasil e mundo), mas também, e principalmente, pela maneira que estas toadas conseguem fazer com que o local se torne global e vice versa, sem ignorar as outras escalas. Por exemplo, a identificação com elementos da cidade de Parintins - algo muito específico e, talvez, com pouco sentido para os turistas - são misturados com discursos de preservação do meio ambiente ou, especificamente neste ano de 2019, discursos feministas.

\section{REFERÊNCIAS}

BRITO, L. M. P.; RIBEIRO, E. M.; SOUZA, T. de. Bois-bumbás de Parintins: síntese metafórica da realidade? In: Revista de Administração Pública. Rio de Janeiro 44(1): 7-30, jan./fev. 2010.

${ }^{68}$ PANTOJA, L. NAKANOME, E. Armadura de fé. In: CAPRICHOSO, Um canto de esperança para Mátria Brasilis. Disponível em: https://boicaprichoso.com/player.asp?t=618.

${ }^{69}$ Idem.

$\begin{array}{llllll}\text { Caminhos de Geografia } & \text { Uberlândia - MG } & \text { v. 22, n. 84 } & \text { dez/2021 } & \text { p. 169-186 } & \text { Página } 183\end{array}$


CARDOSO, M. C. De S. Toadas dos bois-bumbás: memória e arquivo. In: Revista Memento. V.4, n.2, jul.-dez. 2013.

CAVALCANTI, M. L. V. de C. O Boi-Bumbá de Parintins, Amazonas: breve história e etnografia da festa. In: História, Ciência e Saúde. v. VI (supl.), 1019-1046, set. 2000.

CLAVAL, P. A cultura ribeirinha na Amazônia: perspectivas geográficas sobre o papel de suas festas e festejos. In: KOZEL, S.; SILVA, J. C.; FILIZOLA, R.; GIL FILHO, S. F. Expedição Amazônia. Curitiba: SK Ed., 2009.

FIORI, A. L. de; RODRIGUES, R. A. Copa, Estrela e Coração - as cores e os sentidos de Parintins/AM durante a Copa do Mundo no Brasil e o Festival Folclórico do Boi-Bumbá. In: Ponto Urbe [Online], 15, 2014.

FURNALETTO, B. H. Território e identidade no boi-bumbá de Parintins. In: Revista Geográfica de América Central. N. Esp. EGAL, 2011 Costa Rica, II Sem. 2011, pp. 1-15.

GALLEGO CAMPOS, F. R. O conceito de espaço de representação do futebol como possibilidade para a apreensão do futebol profissional e amador como fenômenos da espacialidade. Boletim de Geografia, v. 36, n. 2, p. 1-13, 15 ago. 2018.

GATTO CARDOSO, Y. R.; SOARES, M. C. O Boi-bumbá em Parintins entre Frankfurt e Birmingham: cultura, folclore e comunicação. R. Dito Efeito, Curitiba, v. 8, n. 13, p. 48-60, jul./dez. 2017.

GIL FILHO, S. F. Espaço de representação: uma categoria chave para a análise cultural em geografia. In: I Encontro Sul-Brasileiro de Geografia, 2003, Curitiba: AGB, 2003.

GONZAGA, A. M. A geografia mítica do boi. In: Somanlu, v. 2, n. esp., 2002, p. 137-146.

HAESBAERT, R. O mito da desterritorialização: do "fim dos territórios" à multiterritorialidade. Rio de Janeiro: Bertrand Brasil, 2004.

HALL, S. Identidade cultural na pós-modernidade. Rio de Janeiro: DP\&A, 2005.

LEFEBVRE, H. La presencia y la ausencia. México: FCE, 2006.

. The production of space. Oxford: Blackwell, 1991.

MAFFESOLI, M. Notas sobre a pós-modernidade. Rio de Janeiro: Atlântica, 2004.

O tempo das tribos. Rio de Janeiro: Forense Universitária, 2006.

MAINGUENEAU, D. Novas tendências em análise do discurso. Campinas: Pontes, 1997.

MOSCOVICI, S. Representações sociais. Petrópolis: Vozes, 2003.

PÊCHEUX, M. O discurso: estrutura ou acontecimento. Campinas: Pontes, 2006.

SENA, D da S.; MAISEL, P. de O. P. Festival de Parintins: a epopeia cabocla e a semiose linguística e cultural. In: RELACult, v. 5, ed. esp., maio 2019, p. 1-25.

SHIELDS, R. Lefebvre, love and struggle: spatial dialectics. London: Routledge, 1999.

SILVA, J. M. da. Espetáculo e performance no Festival de Parintins. In: Ilha, v. 11, n.1, 2009, p. 111129.

SILVA, R. G. da. A festa do boi-bumbá e a reprodução da cultura popular. In: Fragmentos de cultura. Goiânia, v. 21, n. 4/6, p. 229-248, abr./jun. 2011.

SILVA, M. A espetacularização da Festa do Boi-Bumbá de Parintins: novos modos de produção artística. In: Cultura Visual, n. 14, dez./2010, Salvador: EDUFBA, p. 23-32.

\section{TOADAS}

AGUIAR, A. Garantido imortal. In: GARANTIDO. Nós, o povo!. Disponível em: https://www.youtube.com/watch?v=f9 2IOQjD6I.

. Povo do garrote. In: GARANTIDO. Nós, o povo!. Disponível em:

https://www.youtube.com/watch?v=gtWBh9OOsvk. 
AGUIAR, A.; VALÉRIO, M.; AGUIAR, V.; MARQUES, N. Legião vermelha. In: GARANTIDO. Nós, o povo!. Disponível em: https://www.youtube.com/watch?v=iQerraf7tll.

ANSELMO, J.; BULCÃO, B.; GADELHA, R.; ANSELMO, N. Meu nome é povão. In: GARANTIDO. Nós, o povo!. Disponível em: https://www.youtube.com/watch?v=ZUhKc02ihr8.

ASSAYAG, R. PANTOJA, L. Mistura de um povo. In: CAPRICHOSO, Um canto de esperança para Mátria Brasilis. Disponível em: https://boicaprichoso.com/player.asp?t=599.

BARBOSA JR., R. Meu Deus é Maria. In: CAPRICHOSO, Um canto de esperança para Mátria Brasilis. Disponível em: https://boicaprichoso.com/player.asp?t=615.

BASTOS, G.; KAWAKAMI, G. Um canto de esperança para Mátria Brasilis. In: CAPRICHOSO, Um canto de esperança para Mátria Brasilis. Disponível em:

https://boicaprichoso.com/player.asp?t=593.

BELO; CIDADE, A. O mais belo de Parintins. In: CAPRICHOSO, Um canto de esperança para

Mátria Brasilis. Disponível em: https://boicaprichoso.com/player.asp?t=601.

DIAS, E.; MOURA, M.; KENNEDY, J. Rosas vermelhas. In: GARANTIDO. Nós, o povo!. Disponível em: https://www.youtube.com/watch?v=RxPkKWDt5DE.

Viva São João. In: GARANTIDO. Nós, o povo!. Disponível em: https://www.youtube.com/watch?v=pr8zExz2X-M.

DIAS, E.; MOURA, M.; KENNEDY, J.; AGUIAR, A. Boi brinquedo de amor. In: GARANTIDO. Nós, o povo!. Disponível em: https://www.youtube.com/watch?v=roPblg2xKFc .

. Nós, o povo! In: GARANTIDO. Nós, o povo!. Disponível em:

https://www.youtube.com/watch?v=H5vEey-6d9c.

. Realeza popular. In: GARANTIDO. Nós, o povo!. Disponível em: https://www.youtube.com/watch?v=C9lY0Fnryko.

DÚ SAGRADO, P. Mátria. In: CAPRICHOSO, Um canto de esperança para Mátria Brasilis. Disponível em: https://boicaprichoso.com/player.asp?t=609.

DÚ SAGRADO, P.; MEDEIROS, A. Rainha do povo azulado. In: CAPRICHOSO, Um canto de esperança para Mátria Brasilis. Disponível em: https://boicaprichoso.com/player.asp?t=596.

FERREIRA, A. MAGNO, L. C.; BULCÃO, M. L. Galope da emoção. In: CAPRICHOSO, Um canto de esperança para Mátria Brasilis. Disponível em: https://boicaprichoso.com/player.asp?t=600.

FILHO, M.; BARBUGIAN, D.; COELHO, J. O melhor boi do mundo. In: GARANTIDO. Nós, o povo!. Disponível em: https://www.youtube.com/watch?v=LvxQ0rigR80.

GÓES, F.; MOURA, M.; AGUIAR, A.; OLIVEIRA, A.; DIAS, E. Festa da liberdade. In: GARANTIDO. Nós, o povo!. Disponível em: https://www.youtube.com/watch?v=fev82q3TIG8.

HAIDOS, D.; ALVINO, V. Batucada perreché. In: GARANTIDO. Nós, o povo!. Disponível em: https://www.youtube.com/watch?v=KAw5H5rfiXg.

KAWAKAMI, G.; BASTOS, G. Tribo Caprichoso. In: CAPRICHOSO, Um canto de esperança para Mátria Brasilis. Disponível em: https://boicaprichoso.com/player.asp?t=595.

LEVY, H.; NEVES, I.; MORENO, M. Erveiras da Amazônia. In: GARANTIDO. Nós, o povo!. Disponível em: https://www.youtube.com/watch?v=-nCde15NwJQ\&pbireload=10.

MAIA, E.; MAIA FILHO, E. Caprichoso: um canto novo de esperança. In: CAPRICHOSO, Um canto de esperança para Mátria Brasilis. Disponível em: $\underline{\text { ttps://boicaprichoso.com/player.asp?t=605. }}$.

MARUPIARA, R.; ALVES, R.; KIMURA, A.; CRUZ, N. Caboclitude. In: GARANTIDO. Nós, o povo!. Disponível em: https://www.youtube.com/watch?v=W-Pg-ju8fkk.

MIRANDA, R.; NOVAES, R.; ROSENHA. A vida me fez Caprichoso. In: CAPRICHOSO, Um canto de esperança para Mátria Brasilis. Disponível em: https://boicaprichoso.com/player.asp?t=598.

MORAES, C.; LIMA, E.; SILVA, D. Rebojo. In: CAPRICHOSO, Um canto de esperança para Mátria Brasilis. Disponível em: https://boicaprichoso.com/player.asp?t=594. 
MORAES, C.; LIMA, E.; VIANA, I. 6 × 0. In: CAPRICHOSO, Um canto de esperança para Mátria Brasilis. Disponível em: https://boicaprichoso.com/player.asp?t=597.

MORAES, C.; SILVA, D.; SANTOS, S. Matriarca. In: CAPRICHOSO, Um canto de esperança para Mátria Brasilis. Disponível em: https://boicaprichoso.com/player.asp?t=606.

NAKANOMI, E.; BARBOSA, R.; BARBOSA JR., R. Boi de encantaria. In: CAPRICHOSO, Um canto de esperança para Mátria Brasilis. Disponível em: https://boicaprichoso.com/player. asp?t=604.

NASCIMENTO, R.; COLARES, M.; AZEVEDO, F. Dança dos Tuxauas. In: CAPRICHOSO, Um canto de esperança para Mátria Brasilis. Disponível em: https://boicaprichoso.com/player.asp?t=612. . Heróis do Brasil. In: CAPRICHOSO, Um canto de esperança para Mátria Brasilis. Disponível em: https://boicaprichoso.com/player.asp?t=603.

PANTOJA, G.; KENNEDY, J.; DIAS, E. Peles vermelhas do Brasil. In: GARANTIDO. Nós, o povo!. Disponível em: https://www.youtube.com/watch?v=LPaeAMWdF0o.

PANTOJA, L. NAKANOME, E. Armadura de fé. In: CAPRICHOSO, Um canto de esperança para Mátria Brasilis. Disponível em: https://boicaprichoso.com/player.asp?t=618.

Recebido em: 25/08/2020

Aceito para publicação em: 19/10/2020 